\title{
MENINGKATKAN MUTU PENDIDIKAN MELALUI SUPERVISI PENDIDIKAN UNTUK MENCAPAI KUALITAS PENDIDIKAN NASIONAL
}

\author{
Oleh : Mia Gusnita \\ E-mail: miagusnita40@gmail.com \\ Universitas Negeri Padang
}

\begin{abstract}
Dari sisi pendidikan kita dapat memahami bahwa supervise pendidikan adalah layanan pemberian bantuan pembinaan yang diberikan oleh supervisor kepada guru dalam upaya meningkatkan kualitas pembelajaran. Didalam dunia sekolah seorang kepala sekolah merupakan supervisor bagi para gurunya, ia memiliki peranan yang pentingdalam membantu para guru untuk meningkatkan kemampuan dan profesionalitas mereka. Namun, meski beberapa kepala sekolah yang merupakan seorang supervisor telah berupaya melakukan tugas dan tanggung jawabnya dalam kegiatan supervise kepada para guru, hasilnya masih jauh dari yang diharapkan.
\end{abstract}

\section{PENDAHULUAN}

Adanya kesan bahwa kehadiran supervisor merupakan hal yang menakutkan bagi para guru dikarenakan sikap supervisor yang memaksakan kehendak, mencari-cari kesalahan, arogan dan sikap negative lainnya, hal tersebut menjadikan guru merasa tidak berdaya. Kondisi ini akan berdampak negative pada motivasi guru dalam mengembangkan kreativitas mereka dalam proses pengajaran.

Karena kurangnya motivasi guru tersebut akibatnya pembelajaran di Indonesia ini belum memenuhi kualitas yang diharapkan, sebagai dampaknya yakni pad prestasi belajar siswa yang belum memuaskan terutama dibandingkan dengan prestasi belajar siswa di negara lainnya. Untuk itu perlu adanya pendekatan peningkatan keprofesionalan guru dengan teknik supervise agar dapat ditumbuhkan budaya organisasi pembelajar dan kegiatan pelatihan.

Dengan menggunaan pendekatan tersebut, dapat meningkatkan kinerja lembaga melalui keprofesionalan guru secara berkelanjutan baik yang dilakukan secara individu maupun kelompok. Bagaimana cara untuk meningkatkan mutu pendidikan melalui supervisi pendidikan?

PENINGKATAN MUTU PENDIDIKAN MELALUI SUPERVISI PENDIDIKAN 
Secara operasional, badan kajian dan pengembangan pendidikan dan kebudayaan menyatakan baha supervise merupakan usaha yang dilakukan dalam rangka memberikan kesempatan kepada para guru untuk mengembangkan diri dan kemampuannya secara professional(Tim dosen AP UPI,2011:313). Artinya supervise bermakna pada pemberian layanan pembinaan kepada para guru yang pada tujuan akhirnya membawa perbaikan pada situasi pendidikan secara umum dan peningkatan kualitas proses belajar mengajar secara khusus.

Supervise dapat dilaksanakan oleh kepala sekolah yang berperan sebagai supervisor, kepala sekolah dalam perannya sebagai supervisor harus melaksanakan tugasnya tersebut dengan cara-cara atau teknik-teknik yang mendidik, dengan memperhatikan karakter guru yang disupervisi sehingga tujuan pemberian supervise dapat dicapai dengan maksimal.

Priansa, dkk(2014:88) menjelaskan tentang fungsi-fungsi kepala sekolah sebagai supervisor yang dikemukakan oleh Ermi Sola (Sola, 2018), yaitu

a) Fungsi penelitian : bertujuan guna mendapatkan gambaran yang jelas dan objektif tentang situasi pendidikan, khusus dalam aspek-aspek supervise dengan melakukan penelitian.

b) Fungsi penilaian : merujuk kepada evaluasi hasil penelitian yang telah dilakukan sebelumnya, baik positif maupun negative.

c) Fungsi perbaikan : merupakan kelanjutan dari fungsi penilaian, hal ini bermakna bahwa ketika penelitian menunjukan hasil yang rendah maka diperlukan perbaikan dalam kegiatan supervise.

d) Fungsi peningkatan: mengacu kepada hasil penelitian yang menunjukkan hasil positif, artinya pelaksaan kegiatan supervise perlu ditingkatkan secara berkesinambungan dan terarah.

Sebagai supervisor di sekolah, kepala sekolah bertanggung jawab mengatur seluruh aspek kurikulum yang berlaku di sekolah agar dapat berjalan dengan lancar sehingga memberikan hasil optimal sesuai target yang telah ditentukan. (Soetopo dan Sumanto, 1998:42) menjelaskan bahwa aspek-aspek kurikulum meliputi: 
1) Membantu guru-guru dalam merencanakan, melaksanakan dan menilai kegiatan program satuan pelajaran.

2) Membantu guru dalam menyusun kegiatan ajar mengajar.

3) Membantu guru dalam menilai proses dari hasil belajar-mengajar.

4) Membantu guru dalam menilai hasil belajar siswa.

5) Membantu guru dalam menterjemahkan kurikulum ke dalam pengajaran.

Dalam meningkatkan mutu pendidikan melalui supervise pendidikan, tidak hanya peran supervisor saja yang dipentingkan peran dari para guru juga berpengaruh terhadap hal tersebut. Maka dari itu dilakukanlah peningkatan keprofesionalan guru untuk meningkatan mutu pendidikan melalui supervise pendidikan dengan menggunakan beberapa pendekatan. Berikut beberapa pendekatan yang dapat dilakukan untuk meningkatttkkkan keprofesionalan guru yang dikemukakan oleh Ahmad Sabandi (Sabandi, 2013):

a) Gaya control directive

Supervise ini digunakan bila guru berada level pengembangan yang rendah : tidak memiliki kemauan dan kecendrungan berbuat.

b) Gaya informational directive

Supervise ini digunakan bila level pengembangan guru agak rendah: tidak memiliki pengetahuan, bingung dan tida berpengalaman.

c) Gaya behaviors collaborative

Supervise ini digunakan bila level pengembangan guru yang moderat, guru dan supervisor memiliki tingkat keahlian yang sama.

d) Gaya behaviors nondirective

Supervise ini digunakan bila level pengembangan guru yang tinggi, guru memiliki keahlian, guru berinisiatif, dan guru berkomitmen.

\section{SIMPULAN}

Supervisi sebagai bagian dari kegiatan administrasi pendidikan yang pada dasarnya merujuk kepada tugas atau pekerjaan seorang supervisor yang memiliki 
kelebihan untuk melihat dan mengawasi pekerjaan orang lain. Dalam upaya menigkatkan mutu pendidikan melalui supervise pendidikan, bukan hanya peran dari supervisor saja yang penting, melainkan peran dari gurunya juga termasuk, kemudian peran orang tua dalam hal mendidik anaknya.

Artinya dalam bidang pendidikan kepala sekolah sebagai supervisor tidak bekerja/menangani sendiri pelaksanaa tugas kesupervisiannya.

\section{SARAN}

Sebagai seorang supervisor pendidikan hendaklah melaksanakan tugas dan fungsinya dengan baik agar tercipta pendidikan yang baik pula, hal ini disampaikan karena masih ada diantara sebagian supervisor pendidikan (kepala sekolah) tidak melaksanakan tugas dan fungsinya sebagai supervisor dengan baik.

\section{DAFTAR PUSTAKA}

Sabandi, A. (2013). Supervisi Pendidikan Untuk Pengembangan Profesionalitas Guru Berkelanjutan. Jurnal Ilmiah Ilmu Pendidikan, XIII(2), 1-9. Retrieved from http://ejournal.unp.ac.id/index.php/pedagogi/article/view/4275

Sola, E. (2018). Ada Apa Dengan Supervisi Pendidikan? Jurnal Idaarah, II(1), 130-140. 